\title{
A Laboratory Bioassay Method to Assess the Use of Toxic Bait on Anastrepha fraterculus (Weidemann 1830)
}

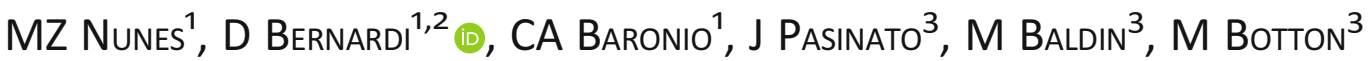 \\ 1 Depto de Fitossanidade, Faculdade de Agronomia, Univ Federal de Pelotas, Pelotas, Rio Grande do Sul, Brazil \\ ${ }^{2}$ Dept of Entomology, Embrapa Clima Temperado, Pelotas, RS, Brazil \\ ${ }^{3}$ Embrapa Uva e Vinho, Bento Gonçalves, Rio Grande do Sul, Brazil
}

\section{Keywords}

Methodology, spinosad, South American fruit fly

\section{Correspondence \\ D. Bernardi, Dept of Entomology, Embrapa \\ Clima Temperado, Pelotas, RS, Brazil; \\ dbernardi2004@yahoo.com.br}

Edited by Geraldo A Carvalho - UFL

Received 25 June 2019 and accepted 1 October 2019

(C) Sociedade Entomológica do Brasil 2019

\begin{abstract}
The lack of standardization of bioassays for the evaluation of toxic bait toxicity on the South American fruit fly, Anastrepha fraterculus (Weidemann 1830), has led to erroneous interpretations of assay results. The objective of this study was to develop a methodology for the standardization and validation of toxicological tests on $A$. fraterculus toxic bait using the Success ${ }^{\mathrm{TM}} 0.02 \mathrm{CB}$ formulation ( $80 \mathrm{mg} \mathrm{L}^{-1}$ of spinosad). Anastrepha fraterculus adults, obtained from larvae reared on an artificial diet, showed higher susceptibility $\left(\mathrm{LT}_{50}=48.96 \mathrm{~h}\right)$ than adults from larvae reared on cattley guava $\left(\mathrm{LT}_{50}=53.83 \mathrm{~h}\right)$ and mango fruit $\left(\mathrm{LT}_{50}=53.55 \mathrm{~h}\right)$. Anastrepha fraterculus adults at the age of five $\left(\mathrm{LT}_{50}=65.30 \mathrm{~h}\right), 15\left(\mathrm{LT}_{50}=\right.$ $59.01 \mathrm{~h})$, and $30\left(\mathrm{LT}_{50}=55.53 \mathrm{~h}\right)$ days presented similar toxicity. The consumption of toxic bait $(4.74 \mathrm{mg})$ increased at 15 days, a fact also observed with insects without food deprivation. In addition, the absence of a food source (artificial diet) with the toxic bait significantly reduced adult mortality time by $7 \mathrm{~h}\left(\mathrm{LT}_{50}=57.42 \mathrm{~h}\right)$. In relation to exposure time, adults exposed to toxic bait for $1 \mathrm{~h}$ reduced consumption by $25 \%$; however, they showed the same susceptibility as insects exposed to $2\left(\mathrm{LT}_{50}=55.72\right.$ $\mathrm{h}), 4\left(\mathrm{LT}_{50}=57.64 \mathrm{~h}\right)$, and $8 \mathrm{~h}\left(\mathrm{LT}_{50}=57.76 \mathrm{~h}\right)$. However, with $24 \mathrm{~h}$ of food deprivation, they had a higher susceptibility $\left(\mathrm{LT}_{50}=46.48 \mathrm{~h}\right)$. Five-day-old A. fraterculus adults fed an artificial diet before being deprived of food for 12 or $24 \mathrm{~h}$, then exposed to toxic bait for $4 \mathrm{~h}$ in the absence of a food source, are considered optimum conditions to evaluate the toxicity of toxic bait.
\end{abstract}

\section{Introduction}

The management of Anastrepha fraterculus (Weidemann 1830) (Diptera: Tephritidae), in Brazilian orchards, has mainly involved the spraying of organophosphorus insecticides (Raga \& Sato 2011; Botton et al 2016). Although this strategy has been effective for several years, organophosphorus insecticides have been restricted in integrated pest management (IPM) due to their high toxicity to mammals, longer pre-harvest interval, and deleterious effect on the natural enemies of pests (Navarro-Llopis et al 2012). Currently, the attract-and-kill technique is being researched worldwide as an alternative insecticide application tool for the control of A. fraterculus (Hafsi et al. 2015).

One attract-and-kill technique involves the use of toxic bait (Raga and Sato 2005, Harter et al 2015, Borges et al 2015, Schutze et al 2018). Toxic baits are composed of sugar- and protein-based food attractants mixed with lethal agents (insecticides) that aim to attract adult insects, induce ingestion, and promote death (Raga \& Galdino 2018). Adult, particularly female, fruit flies need protein and sugar to fuel sexual development and reproduction (Raga \& Sato 2005). 
In Brazil, sugarcane molasses (a by-product of the sugar manufacturing process that contains reducing sugars and non-crystallized sucrose) has been the most commonly used attractant in toxic bait formulations (Raga et al 2006). However, its use has caused variability in fruit fly control in several regions due to the lack of standardization, which has tended to invalidate this technique for pest management (Raga et al 2006, Borges et al 2015, Harter et al 2015, Botton et al 2016). However, advances in research have led to new formulations of food attractants, such as Biofruit ${ }^{\mathrm{TM}}$ (BioControle Métodos de Controle de Pragas Ltda., Indaiatuba, São Paulo, Brazil), CeraTrap ${ }^{\mathrm{TM}}$ and Flyral ${ }^{\mathrm{TM}}$ (Biolbérica S.A., Barcelona, Spain), Isca Samaritá ${ }^{T M}$ and Traditional SamaritáTM (Samaritá Indústria e Comércio Ltda., Artur Nogueira, São Paulo, Brazil) (Botton et al 2016). In addition, there are ready-to-use formulations, such as Success ${ }^{\circledR} 0.02 \mathrm{CB}$ (the same as the widely used bait GF-120 ${ }^{\circledR}$ NF fruit fly toxic bait) and Gelsura ${ }^{\mathrm{TM}}$ (Jang et al 2005).

In literature, there is information on the use of fly adults from naturally infested fruits in the field (Da Cruz et al 1997) or of rearing of laboratory from of fruits of papaya (Borges et al 2015). Similarly, the use of insects with age between 1 and 7 days (Raga \& Sato 2005), 1 to 3 days (Raga \& Sato 2011), or 30 days (Da Cruz et al 1997). The period of food deprivation prior to the installation of the bioassay was not mentioned in the studies (Raga \& Sato 2011). However, these factors may change the susceptibility of insects over time, as verified for Ceratitis capitata (Wiedemann) (Diptera: Tephritidae) (Barronio et al 2019). In view of the need for standardized bioassays for conducting toxicity studies and in the selection of new formulations of toxic bait for A. fraterculus, this study aimed to develop a methodology for the evaluation of toxic bait formulations on adults of A. fraterculus, using as a toxicity model the ready-to-use formulation Success ${ }^{\mathrm{TM}}$ 0.02CB.

\section{Materials and Methods}

\section{Insects and bioassays}

The insects for the bioassays (artificial diet with toxic bait availability, exposure time of toxic bait, toxicity of toxic bait as a function of age and period of food deprivation prior to toxic bait exposure to adults of $A$. fraterculus) came from a susceptible population of $A$. fraterculus, which was kept in the laboratory in the artificial diet for 5 years, free of selection pressure by insecticides, following the methodology proposed by Machota-Jr et al (2010). However, for the bioassay (susceptibility of $A$. fraterculus populations as a function of origin), insects from three different sources of larval development (treatments) were evaluated: (i) adults (1st generation) from A. fraterculus larvae collected in the field from native fruits of red cattley guava (Psidium cattleyanum); (ii) adults (12th generation) from larvae reared on mango fruit (Mangifera indica) as the substrate for larval development in the laboratory; and (iii) adults (12th generation) from larvae rearing on the artificial diet in the laboratory (Nunes et al 2013). All bioassays were kept in air-conditioned rooms (temperature of $25 \pm 2^{\circ} \mathrm{C}$, relative air humidity of $70 \pm 10 \%$, and photophase of $12 \mathrm{~h}$ ).

For the bioassays, adults of $A$. fraterculus were packed inside plastic containers $(12.0 \mathrm{~cm}$ diameter by $10.0 \mathrm{~cm}$ tall) (300 $\mathrm{mL}$ ), as proposed by Machota-Jr et al (2010). The toxic bait used in the bioassays was Success ${ }^{\mathrm{TM}}$ 0.02CB (Dow Agrosciences, Santo Amaro, São Paulo, Brazil), and a readyto-use formulation was used as a standard for adult A. fraterculus toxicity. The formulation was diluted in the ratio of one-part commercial product to 1.5-part water, resulting in a concentration of $80 \mathrm{mg} \mathrm{L}^{-1}$ of spinosad. The bait was offered in the form of a $40-\mu \mathrm{L}$ drop deposited on a plastic plate $\left(1 \mathrm{~cm}^{2}\right)$ of ethyl poly terephthalate (PET) with the aid of graduated single-channel micropipette Gilson ${ }^{\mathrm{TM}}$ model Pipetman (U76928A with $1 \mathrm{~mL}$ capacity). The bait was then dried for $2 \mathrm{~h}$ at $25^{\circ} \mathrm{C}$. After the withdrawal of the toxic bait, the insects were fed an artificial diet composed of a mixture of wheat germ, beer yeast, and brown sugar (3:1:1) supplied in acrylic lids ( $2 \mathrm{~cm}$ diameter), and distilled water was provided in plastic caps ( $2 \mathrm{~cm}$ diameter) lined with hydrophilic cotton (Machota-Jr et al 2010). The mortality of $A$. fraterculus adults in all bioassays was evaluated at 1, 3, 6, 12, 24, 48, 72, and 96 hours after exposure (HAE) of the toxic bait, and $L_{50}$ values were estimated. Adult mortality of $A$. fraterculus was corrected by the formula of Abbott (1925). All bioassays were conducted in a completely randomized manner with 17 replicates per treatment, each replicate consisting of six A. fraterculus adults (three couples) and repeated twice over time, totaling 204 insects per bioassay.

\section{Susceptibility of $\boldsymbol{A}$. fraterculus populations as a function of origin}

Insects from three different sources of larval development (treatments) were evaluated: (i) adults (1st generation) from A. fraterculus larvae collected in the field from native fruits of red cattley guava (Psidium cattleyanum); (ii) adults (12th generation) from larvae reared on mango fruit (Mangifera indica) as the substrate for larval development in the laboratory; and (iii) adults (12th generation) from larvae raised on the artificial diet in the laboratory (Nunes et al 2013). The adults that emerged from the different development substrates were maintained and reared in semitransparent plastic cages $(41 \times 29.5 \times 30 \mathrm{~cm}$ in length, width, and height, respectively), with water supplied in polyurethane sponges and an artificial diet, as proposed by Machota-Jr et al (2010). For the bioassays, 5 - to 8-day-old adult $A$. fraterculus of both populations were packed inside plastic containers $(12.0 \mathrm{~cm}$ 
diameter by $10.0 \mathrm{~cm}$ tall) $(300 \mathrm{~mL})$, and fed with a toxic bait (Success $^{\mathrm{TM}} 0.02 \mathrm{CB}$, one drop of $40 \mu \mathrm{L}$ ) for a period of $2 \mathrm{~h}$. After this time, the toxic bait was removed, and the insects fed with water and artificial diet until the end of the bioassay (Machota-Jr et al 2010). The negative control adults of A. fraterculus were fed only the artificial diet.

\section{Toxicity of toxic bait on adults of $\boldsymbol{A}$. fraterculus as a function of age}

The effect of adult age on $A$. fraterculus mortality from ingestion of the Success ${ }^{\mathrm{TM}}$ 0.02CB bait was evaluated using insects at the age of 5,15 , and 30 days after emergence. The insects were packed into plastic containers $(300 \mathrm{~mL})$, and the toxic bait (Success ${ }^{\mathrm{TM}} \mathrm{0.02 \textrm {CB }}$, one drop of $40 \mu \mathrm{L}$ ) was provided for a 4 -h period, as described above. After this period, the toxic bait was removed and the insects were fed artificial diet and water.

\section{Artificial diet with toxic bait availability}

Adults of $A$. fraterculus (5 to 8 days old), obtained from the group maintained on the artificial diet, were placed inside plastic containers $(12.0 \mathrm{~cm}$ diameter by $10.0 \mathrm{~cm}$ tall) (300 $\mathrm{mL}$ ). To verify the effects of the presence or absence of the artificial diet on adults of $A$. fraterculus, during the period of exposure to the toxic bait, the treatments $(T)$ were formulated as follows: treatment $1\left(\mathrm{~T}_{1}\right)$ adults of $A$. fraterculus were exposed only to toxic bait (Success ${ }^{\mathrm{TM}} \mathrm{O.02CB}$, one drop of 40 $\mu L)+$ distilled water as feed substrates; treatment $2\left(T_{2}\right)$ adults of $A$. fraterculus were exposed to the toxic bait Success $^{\mathrm{TM}} 0.02 \mathrm{CB}$ (one drop of $40 \mu \mathrm{L}$ ) + distilled water + artificial diet.

\section{Exposure duration of $\boldsymbol{A}$. fraterculus adults to toxic bait}

Adult $A$. fraterculus (5 to 8 days old), obtained from the group maintained in the artificial diet, were packed inside plastic containers (12 cm diameter by $10 \mathrm{~cm}$ tall) $(300 \mathrm{~mL})$, as previously described. The insects were exposed to toxic bait Success ${ }^{\mathrm{TM}} 0.02 \mathrm{CB}$ (one drop of $40 \mu \mathrm{L}$ ), without the presence of artificial diet for 1, 2, 4, and $8 \mathrm{~h}$. After the determined exposure periods, the toxic bait was withdrawn and artificial diet was offered to the adults until the end of evaluation.

\section{Period of food deprivation prior to toxic bait exposure}

Adults of $A$. fraterculus ( 5 to 8 days old), obtained from the group maintained in the artificial diet, were submitted to periods of o (no deprivation), 12, and $24 \mathrm{~h}$ of food deprivation. After this time, they were transferred to plastic cages containing the Success ${ }^{\circledR}$ 0.02CB bait + distilled water + artificial diet. The toxic baits were provided for $4 \mathrm{~h}$, as described above. As a negative control (control treatment), the insects received only artificial diet and water.

\section{Data analysis}

The determination of the consumption of the toxic baits was carried out by weighing the blade in a precision scale (Mettler Toledo, model MS204S/A01), and subtracting the final mass (FM) from the initial mass (IM). The possible evaporation of the toxic bait was corrected by the evaporation of the toxic bait-containing plates that were kept in the same conditions for each experiment (negative control), but without being offered to the insects. The data on mortality (\%) and consumption of toxic bait were submitted to studentized residual analyses to confirm the assumption of normality using the Shapiro-Wilk test with the PROC UNIVARIATE (ANOVA) using the $F$ test $(P<0.05)$ (PROC GLM, SAS Institute 2011). Finding statistical significance, the averages were compared by the Tukey test at a $5 \%$ level of significance $(P<0.05)$. The resulting percentage data were submitted to arcsine square root transformation, prior to analysis using the SAS function ARSIN (SQRT[x]). After arcsine square root transformation, the data met the assumption of normality required for ANOVA tests and treatment differences were determined using least-square means statements (LSMEANS) at a $P=0.05$ level of significance. For the evaluation of the effect of each treatment on insect survival, survival curves and respective lethal times $\left(\mathrm{LT}_{50}\right)$ were determined through the Kaplan-Meier analysis, and comparing the survival curves by the log-rank test through the program SigmaPlot (v.12.5, Systat Software Inc., California, USA).

\section{Results}

\section{Susceptibility of $\boldsymbol{A}$. fraterculus populations to toxic bait}

Insects on an artificial diet showed a higher susceptibility to 96-HAET (98\% mortality), giving a lower $\mathrm{LT}_{50}\left(\mathrm{LT}_{50}[95 \% \mathrm{Cl}]=\right.$ 48.96 [46.96-50.86] h) relative to adults of $A$. fraterculus from cattley guava fruit (mortality of $78 \%)\left(\mathrm{LT}_{50}[\mathrm{Cl} 95 \%]=\right.$ 53.83 [51.71-56.5] h) and mango fruit (88\% mortality) ( $\mathrm{LT}_{50}$ [Cl 95\%] = 53.55 [51.41-55.59] h) (Table 1; Fig 1). However, no significant differences were observed in the consumption of toxic bait in relation to the origin of the insects (Table 1).

Influence of age on the toxicity of toxic bait to $A$. fraterculus

Adult 5 and 15-day-old A. fraterculus (92\% mortality) presented the same susceptibility as 30 -day-old insects (100\% mortality) and 96 HAE (Table 1), a fact that was seen when the survival curves were analyzed in relation to $L T_{50}$ values $\left(L_{50}\right.$ ranging from 55.53 to $65.30 \mathrm{~h}$ ) (Table 1; Fig 2). However, 15- 
Table 1 Percentage of mortality (\% M), lethal time in hours (LT50), confidence interval (Cl), and toxic bait consumption (mg) of Anastrepha fraterculus adults in ingestion bioassay when submitted to the Success ${ }^{\mathrm{TM}} 0.02 \mathrm{CB}$ toxic bait formulation.

\begin{tabular}{|c|c|c|c|}
\hline Bioassay & $\begin{array}{l}96 \mathrm{HAE} \\
\% \mathrm{M}^{1}\end{array}$ & $\mathrm{LT}_{50}(\mathrm{Cl} 95 \%)(\mathrm{h})^{2}$ & Toxic bait consumption $(\mathrm{mg})^{3}$ \\
\hline \multicolumn{4}{|c|}{ Susceptibility of $A$. fraterculus population } \\
\hline Fruits of cattley guava & $78.0 \pm 1.34 \mathrm{a}$ & $53.83(51.71-56.15)$ & $7.01 \pm 2.07 a$ \\
\hline Fruits of mango & $88.3 \pm 1.27 \mathrm{~b}$ & $53.55(51.41-55.59)$ & $6.79 \pm 2.32 \mathrm{a}$ \\
\hline Artificial diet & $98.2 \pm 1.15 \mathrm{C}$ & $48.91(46.96-50.86)$ & $8.12 \pm 2.77 \mathrm{a}$ \\
\hline \multicolumn{4}{|c|}{ Influence of $A$. fraterculus age on toxicity of toxic bait } \\
\hline 5 days old & $92.6 \pm 1.24 \mathrm{a}$ & $65.30(63.49-69.13)$ & $5.30 \pm 0.20 \mathrm{a}$ \\
\hline 15 days old & $92.1 \pm 2.10 \mathrm{a}$ & $59.01(57.12-65.89)$ & $4.74 \pm 1.50 \mathrm{~b}$ \\
\hline 30 days old & $100.0 \mathrm{~b}$ & $55.53(51.76-65.14)$ & $5.75 \pm 0.80 \mathrm{a}$ \\
\hline \multicolumn{4}{|c|}{ Availability of artificial diet with toxic bait } \\
\hline Toxic bait + artificial diet & $85.5 \pm 1.17 a$ & $64.64(62.64-66.64)$ & $2.1 \pm 0.50 \mathrm{~b}$ \\
\hline Toxic bait & $96.1 \pm 0.97 b$ & $57.42(51.52-59.33)$ & $2.9 \pm 0.90 \mathrm{a}$ \\
\hline \multicolumn{4}{|c|}{ Exposure duration of $A$. fraterculus adults to toxic bait } \\
\hline $1 \mathrm{~h}$ & $77.4 \pm 2.10 \mathrm{a}$ & $55.98(52.78-59.18)$ & $6.22 \pm 1.76 b$ \\
\hline $2 \mathrm{~h}$ & $95.3 \pm 1.16 b$ & $55.72(52.83-58.61)$ & $8.42 \pm 2.42 \mathrm{a}$ \\
\hline $4 \mathrm{~h}$ & $98.2 \pm 2.02 b$ & $57.64(55.46-59.83)$ & $8.48 \pm 2.54 a$ \\
\hline $8 \mathrm{~h}$ & $98.4 \pm 1.65 b$ & $57.76(55.59-59.94)$ & $8.07 \pm 2.48 \mathrm{a}$ \\
\hline \multicolumn{4}{|c|}{ Time of food diet deprivation } \\
\hline o-h deprivation & $77.3 \pm 1.12 \mathrm{a}$ & $56.77(53.27-60.28)$ & $2.14 \pm 0.86 b$ \\
\hline 12-h deprivation & $88.5 \pm 2.10 b$ & $50.19(47.67-52.71)$ & $2.96 \pm 0.72 a$ \\
\hline 24-h deprivation & $90.2 \pm 1.76 b$ & $46.48(44.37-47.59)$ & $2.96 \pm 0.13 a$ \\
\hline
\end{tabular}

${ }^{1}$ Mortality calculated by the formula of Abbott (1925)

${ }^{2} \mathrm{LT}_{50}=$ time required to kill $50 \%$ of a tested population

${ }^{3}$ Estimated value through subtraction of the initial mass (IM) from the final mass (FM) in each blade. A separate ANOVA (Tukey's test, $P<0.05$ ) was conducted for treatments within each column (means followed by the same letter in column are not significantly different)

day-old insects consumed less toxic bait $(4.74 \mathrm{mg})(F=3.86$; $\mathrm{df}=2 ; P<0.0001)$ compared with adults of 5 days $(5.66 \mathrm{mg})$ and 30 days $(5.75 \mathrm{mg}$ ) (Table 1$)$.

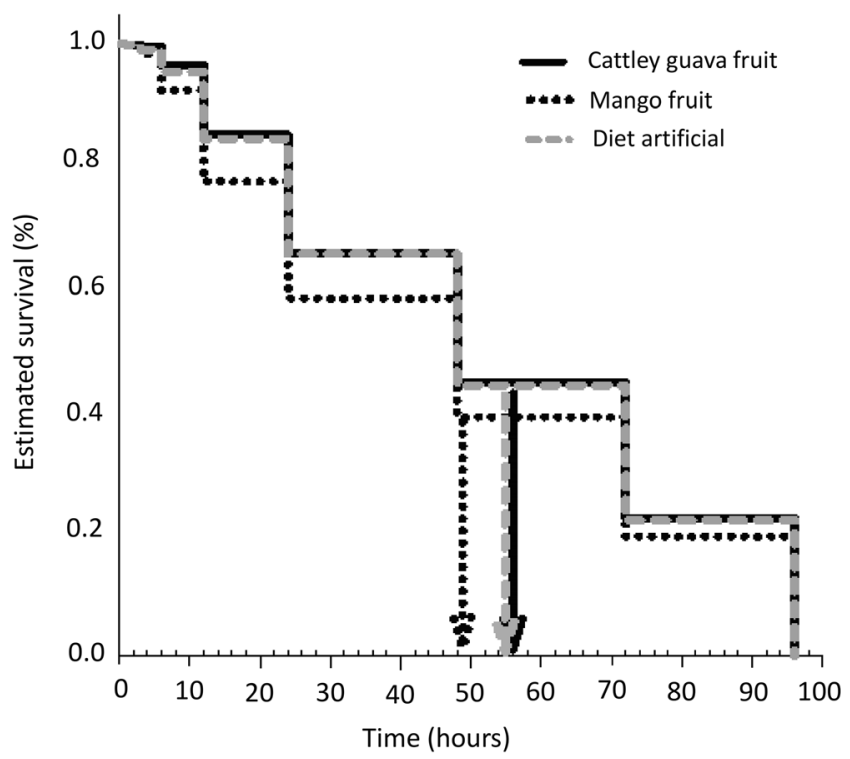

Fig 1 Survival of Anastrepha fraterculus adults from larvae reared in fruit of cattley guava (wild population), mango, and artificial diet (laboratory population) and exposed to the toxic bait Success ${ }^{\mathrm{TM}}$ $0.02 \mathrm{CB}$, containing $80 \mathrm{mg} \mathrm{L}^{-1}$ of spinosad in the laboratory. Arrows indicate the lethal time $\left(\mathrm{LT}_{50}\right)$ of the Success ${ }^{\mathrm{TM}}$ 0.02CB toxic bait in each parameter evaluated.

\section{Effect of availability of artificial diet}

Based on the absence of the overlap of confidence interval, adult $A$. fraterculus presented lower lethal time $\left(\mathrm{LT}_{50}[\mathrm{Cl}\right.$

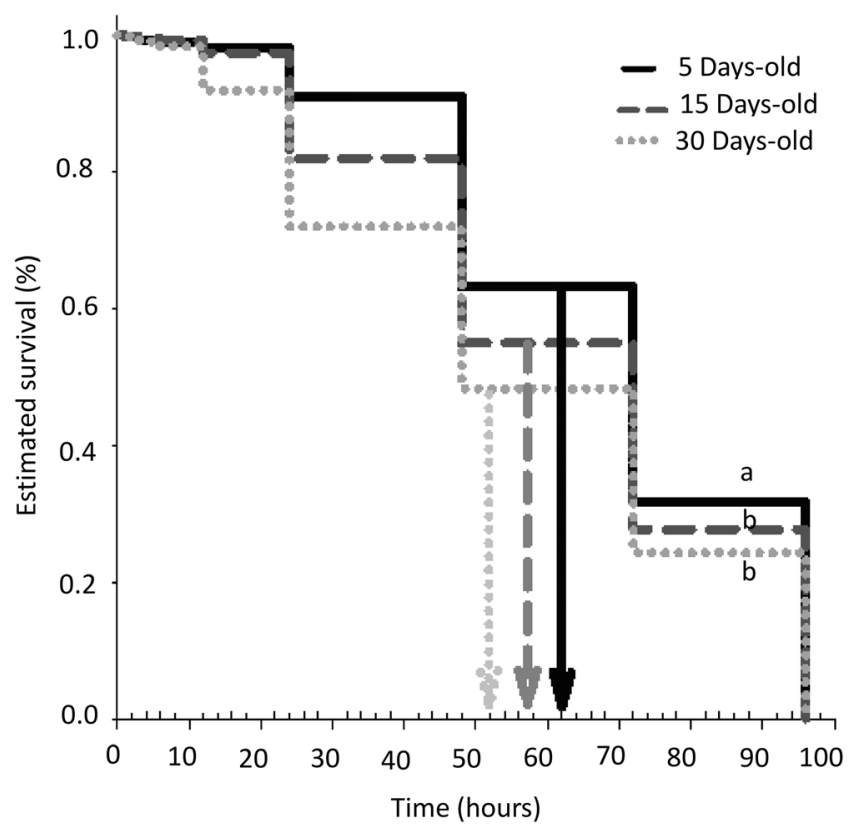

Fig 2 Survival of 5-, 15-, and 30-day-old Anastrepha fraterculus adults exposed to the toxic bait Success ${ }^{\mathrm{TM}} 0.02 \mathrm{CB}$, containing $80 \mathrm{mg} \mathrm{L}^{-1}$ of 
$95 \%]=64.64[62.64-66.64]$ h) when they were offered feeding + artificial diet, causing a mortality of $85 \%$ of the insects at 96 HAE. However, when the insects received only toxic bait $\left(\mathrm{LT}_{50}[\mathrm{Cl} 95 \%]=57.42[51.52-59.33] \mathrm{h}\right)$, they had 96\% mortality up to 96 HAE (Table 1 ; Fig 3 ). Adult $A$. fraterculus consumed less toxic bait $(2.1 \mathrm{mg})(t=3.58, \mathrm{df}=37, P<0.001)$ when artificial diet was provided with water + Success ${ }^{\mathrm{T} M}$ $0.02 \mathrm{CB}$ formulation, compared with insects that received only the toxic bait $(2.9 \mathrm{mg}$ ) (Table 1).

\section{Exposure duration of $\boldsymbol{A}$. fraterculus adults to toxic bait}

Although adults of $A$. fraterculus showed significantly lower mortality when exposed to $1 \mathrm{~h}$ of toxic bait $(77 \%$ mortality up to $96 \mathrm{HAE}$ ), compared with 2-h ( $95 \%$ mortality) and 4 and 8-h exposure ( $98 \%$ of mortality), there was no difference in relation to $\mathrm{LT}_{50}\left(\mathrm{LT}_{50}\right.$ ranging from 55.72 to $57.76 \mathrm{~h}$ ) (Table 1; Fig 4). However, insects that were exposed for $1 \mathrm{~h}$ consumed less toxic bait $(6.22 \mathrm{mg})(F=8.97 ; \mathrm{df}=3 ; P<0.001)$ than insects that were fed for $2 \mathrm{~h}(8.42 \mathrm{mg}), 4 \mathrm{~h}(8.48 \mathrm{mg})$, and $8 \mathrm{~h}(8.07$ mg) (Table 1).

\section{Period of food deprivation before exposure of $\boldsymbol{A}$. fraterculus} to toxic bait

Adult $A$. fraterculus maintained without food deprivation were less susceptible to toxic bait ( $77 \%$ mortality at $96 \mathrm{HAE}$ ) than insects that were maintained for $12 \mathrm{~h}$ (88\% mortality) and $24 \mathrm{~h}$ (90\% mortality) with food

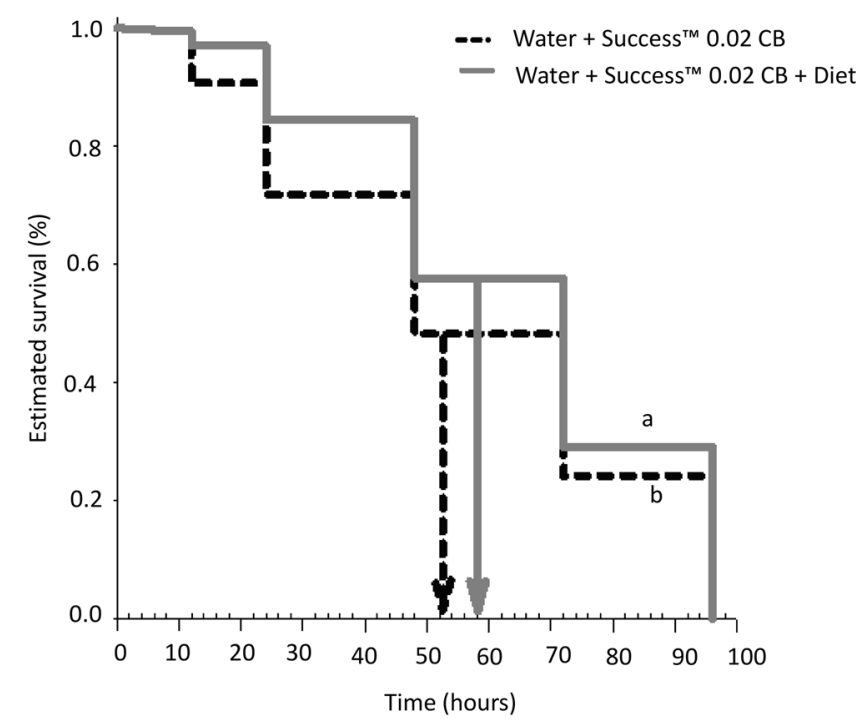

Fig 3 Survival of Anastrepha fraterculus adults after exposure to the toxic bait Success ${ }^{\mathrm{TM}} 0.02 \mathrm{CB}$, containing $80 \mathrm{mg} \mathrm{L}^{-1}$ of spinosad alone or with artificial diet in the laboratory. Arrows indicate the lethal time $\left(\mathrm{LT}_{50}\right)$ of the Success ${ }^{\mathrm{TM}} \mathrm{O}$.02CB toxic bait in each parameter evaluated.

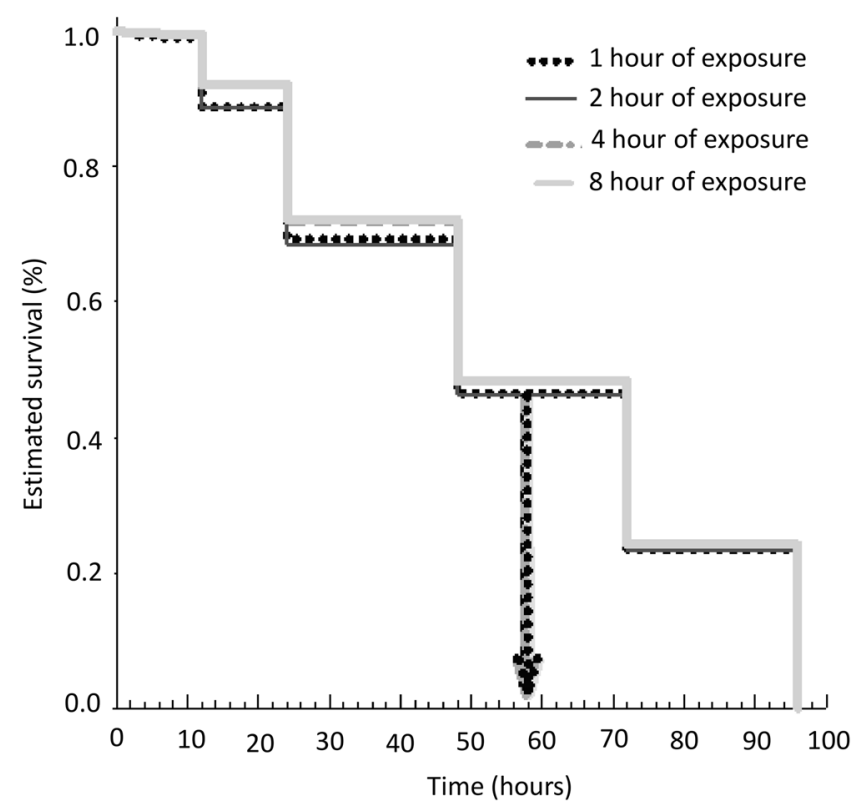

Fig 4 Survival of Anastrepha fraterculus adults after exposure to the toxic bait Success $\mathrm{s}^{\mathrm{TM}} 0.02 \mathrm{CB}$, containing $80 \mathrm{mg} \mathrm{L}^{-1}$ of spinosad offered for $1,2,4$, and $8 \mathrm{~h}$ in the laboratory. Arrows indicate the lethal time $\left(\mathrm{LT}_{50}\right)$ of the Success ${ }^{T M}$ 0.02CB toxic bait in each parameter evaluated.

deprivation (Table 1). However, adults with $24 \mathrm{~h}$ of food deprivation had the lowest values of $\mathrm{LT}_{50}\left(\mathrm{LT}_{50}\right.$ $[\mathrm{Cl} 95 \%]=46.48$ [44.37-47.59] h) (Table 1; Fig 5), compared with insects kept for $12 \mathrm{~h}$ with food deprivation $\left(\mathrm{LT}_{50}[95 \% \mathrm{Cl}]=50.19[47.67-52.71] \mathrm{h}\right)$ and no food deprivation $\left(\mathrm{O}\right.$ h) $\left(\mathrm{LT}_{50}[95 \% \mathrm{Cl}]=56.77[53.77-\right.$ 60.28] h) (Table 1; Fig 5). However, adults without food

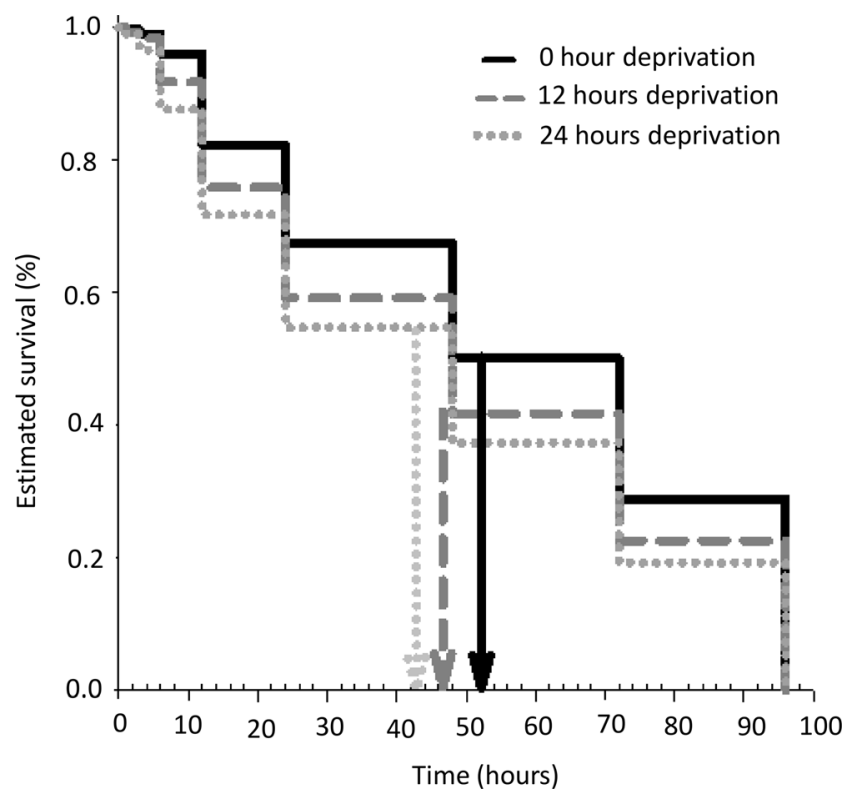

Fig 5 Survival of Anastrepha fraterculus adults submitted to o-h, 12-h, and 24-h deprivation periods and exposed to the toxic bait Success ${ }^{\mathrm{TM}}$ $0.02 \mathrm{CB}$, containing $80 \mathrm{mg} \mathrm{L}^{-1}$ of spinosad in the laboratory. Arrows 
deprivation consumed less toxic bait $(2.14 \mathrm{mg})(F=$ 12.82; $\mathrm{df}=2 ; P<0.0001)$ than insects that were kept in food deprivation for 12 and $24 \mathrm{~h}$ (2.96 mg) (Table 1).

\section{Discussion}

Defining an appropriate methodology to evaluate the efficiency of toxic bait for fruit fly management is of paramount importance in the design of management strategies (Gazit et al. 2013, Paramasivam \& Selvi 2017, Baronio et al 2019). The variability of bait efficiency mainly stems from the availability of different food attractants for toxic bait formulations (Botton et al 2016; Raga \& Galdino 2018). According to Robertson et al (2007), the lack of experimental standardization in the evaluation of toxicity bioassays of arthropod pests can lead to questions about the efficiency of a given product and the replicability of the bioassays.

In the present study, the ready-to-use toxic bait Success ${ }^{\mathrm{TM}}$ $0.02 \mathrm{CB}$ was used to define the bioassay methodology using $A$. fraterculus. This is a trademarked and commercially standardized formulation for the management of $A$. fraterculus and $C$. capitata in several crops in Brazil. In addition, it presents high toxicity to adults of different fruit fly species (Gazit et al 2013, Harter et al. 2015, Baronio et al. 2019).

Adult $A$. fraterculus, from larvae reared in the laboratory on an artificial diet (for 12 generations), were more susceptible to the same quantity $(\mathrm{mg})$ of bait compared with adults from larvae collected in the field or from larvae raised in the laboratory but fed mango fruit. In view of these results, it is evidenced that the origin of the population directly influences the toxicity of the toxic bait, as observed for C. capitata (Baronio et al. 2019).

The lower susceptibility of $A$. fraterculus (1st generation) adults from field insects compared with adults from larvae reared on an artificial diet may be associated with a greater activation of detoxifying enzymes induced by allelochemicals present in the larval stage food source (Van Den Bosch \& Welte 2016). The larval development of $A$. fraterculus in cattley guava or mango fruit may have triggered an increase in the amount of detoxifying symbioses that help protect the body against toxic substances (Prokopy et al 1993; Van Den Bosch \& Welte 2016). In addition, the field population may undergo changes in the allelic frequency of insecticide resistance genes for spinosad, a toxin present in the Success ${ }^{\mathrm{TM}}$ $0.02 \mathrm{CB}$ formulation. Although there are no reported cases of $A$. fraterculus resistance to insecticides in Brazil (Raga et al 2018), the high selection pressure caused by spinosyn-based chemical application over a wide area during the harvest can promote changes in genetic variability and in the insect's response to the toxic bait (Raga \& Galdino 2018).

The supply of a food source (artificial diet) concomitantly with the toxic bait prolonged the survival period of the insects, providing a higher value of $\mathrm{LT}_{50}$. This fact may be associated with the lower consumption of toxic bait by adults of A. fraterculus. As the efficiency of the toxic bait depends on the amount of active ingredient ingested, the greater the amount of bait ingested, the greater the possibility of intoxication by the lethal agent and, consequently, the faster the insect mortality (Medina et al 2007; Gazit et al 2013). Moreover, the availability of an alternative food source (artificial diet), along with exposure to the Success ${ }^{\mathrm{TM}} 0.02 \mathrm{CB}$ formulation for $4 \mathrm{~h}$, enabled $A$. fraterculus adults to choose which food source to ingest. This may have resulted in an underestimation of the actual lethal dose of the ingested toxic bait, especially when the lethal agent does not show fast action (knock-down effects), such as spinosad (Gazit et al 2013; Raga \& Galdino 2018).

The implementation of a period of food deprivation (12 and $24 \mathrm{~h}$ ) of $A$. fraterculus adults, prior to the beginning of the bioassays, induced the insects to search for the food source when it was offered, leading to a greater consumption of toxic bait. This type of behavior is explained by the "compensation reaction" caused by the time in which the insects remained without food (Manrakhan \& Lux 2008; Yee \& Alston 2016). The higher consumption of toxic bait during the same bait exposure period ( $4 \mathrm{~h}$ ), for food-deprived insects, promoted a greater ingestion of the toxin present in the formulation, which resulted in greater toxicity to the insects and lower values of $\mathrm{LT}_{50}$. However, it should be noted that periods of prolonged deprivation (above $24 \mathrm{~h}$ ) showed an increase in adult mortality (data not reported) in the present study.

Several studies have demonstrated that insects, especially A. fraterculus adults with an age range of 5 to 8 days after emergence, need to ingest nutrients to maintain energy reserves, and to fuel copulation and maturation of the reproductive system (Kapsi et al 2002, Raga \& Sato 2018). This was evidenced in the present study when adults of $A$. fraterculus of different ages $(5,15$, and 30 days after emergence) were tested. In the case of $A$. fraterculus, the highest food intake occurred at 5 and 30 days after emergence (DAE); this may be related to the need for an increased intake of protein for the development of the ovaries during the initial phase (5 days) and to prepare for copulation and oviposition (Rull \& Prokopy 2000): the pre-oviposition period of $A$. fraterculus occurs at approximately 12 days of age (Zart et al 2010). However, the intake of higher amounts of protein by insects at 30 DAE is related to the physiological and natural behavior of the species in prolonging the life cycle, which allows for an increase in the period in which adults can remain in the field to infest fruit (Kouloussis et al 2017).

According to the results, the origin of the population, the form and time of toxic bait supply, the period of food deprivation, and the age of insects directly influence on insect mortality in toxicological tests in the laboratory. For A. fraterculus, the use of 5-day-old insects, deprived of food for 12 or $24 \mathrm{~h}$, and exposed to the toxic bait for $4 \mathrm{~h}$ is suitable for the 
development and validation of laboratory bioassays for toxic bait. Although insects grown on natural fruit should preferably be used in toxicological tests because they resemble wild insects, our research group recommends using laboratoryreared insects, as wild field populations may suffer from changes in the allelic frequency of genes associated with resistance and not show the same toxicological response to toxic bait.

Author Contribution Statement $\mathrm{MZN}, \mathrm{CAB}$, and JP conceived and designed the research. MZN, CAB, JP, and $M B$ conducted experiments. MZN and DB analyzed the data. MZN and DB wrote the manuscript. All authors reviewed and approved the manuscript.

\section{References}

Abbott WS (1925) A method of computing the effectiveness of an insecticide. J Econ Entomol 18:265-267

Barronio CA, Bernardi D, Nunes MZ, Pasinato J, Garcia FRM, Botton M (2019) Bioassay method for toxicity studies of toxic bait formulations to Ceratitis capitata (Diptera: Tephritidae). Neotrop Entomol 48:356363

Borges R, Machota JR, Boff MIC, Botton M (2015) Efeito de iscas tóxicas sobre Anastrepha fraterculus (Wiedemann) (Diptera: Tephritidae). Bioassay 10:1-8

Botton M, Arioli CJ, Machota-Jr R, Nunes MZ, Rosa JM (2016) Moscasdas-frutas na fruticultura de clima temperado: situação atual e perspectivas de controle através do emprego de novas formulações de iscas tóxicas e da captura massal. Rev Agropec Catarinense 29: 103-107

Da Cruz IBM, Humeres E, Oliveira AK (1997) Toxicity of fenthion to Anastrepha fraterculus (Wied.) (Diptera: Tephritidae): dose response analysis. An Soc Entomol Bras 26:471-479

Gazit Y, Gavriel S, Akiva R, Rimar D (2013) Toxicity of baited spinosad formulations to Ceratitis capitata: from the laboratory to the application. Entomol Exp Appl 147:120-125

Hafsi A, Abbes K, Harbi A, Duyck PF, Chermiti B (2015) Evaluation of the efficiency of mass trapping of Ceratitis capitata (Wiedemann) (Diptera: Tephritidae) in tunisian citrus orchards using two types of traps: Ceratrap ${ }^{\circledR}$ and Tripack $^{\circledR}$. Acta Hortic 1065:1049-1056

Härter WR, Botton $M$, Nava $D E$, Grutzmacher $A D$, Gonçalves RS, Machota-Jr R, Bernardi D, Zanardi OZ (2015) Toxicities and residual effects of toxic baits containing spinosad or malathion to control the adult Anastrepha fraterculus (Diptera: Tephritidae). Fla Entomol 98: 202-208

Jang EB, Khrimian A, Holler TC, Casana-Giner V, Lux S, Carvalho LA (2005) Field response of Mediterranean fruit fly (Diptera: Tephritidae) to Ceralure B1: evaluations of enantiomeric B1 ratios on fly captures. J Econ Entomol 98:1139-1143

Kapsi R, Mossinson S, Drezner T, Kamensky B, Yuval B (2002) Effects of larval diet on development rates and reproductive maturation of male and female Mediterranean fruit flies. Physiol Entomol 27:29-38

Kouloussis NA, Damos PT, loannou CS, Tsitsoulas C, Papadopoulos NT, Nestel D, Koveos S (2017) Age related assessment of sugar and protein intake of Ceratitis capitata in ad libitum conditions and modeling its relation to reproduction. Front Physiol 8:1-13

Machota-Jr R, Bortoli LC, Tolotti A, Botton M (2010) Técnica de criação de Anastrepha fraterculus (Diptera: Tephritidae) em laboratório utilizando hospedeiro natural. Boletim de Pesquisa e Desenvolvimento, Embrapa Uva e Vinho 15:23

Manrakhan A, Lux AS (2008) Effect of food deprivation on attractiveness of food sources, containing natural and artificial sugar and protein, to three African fruit flies: Ceratitis cosyra, Ceratitis fasciventris, and Ceratitis capitata. Entomol Exp Appl 27:133-143

Medina P, Perez I, Budia F, Adan A, Vinuela E (2007) Development of an extended-laboratory method to test novel insecticides in bait formulation. IOBC/WPRS Bull 26:59-66

Navarro-Llopis V, Primo J, Vacas S (2012) Efficacy of attract-and-kill devices for the control of Ceratitis capitata. Pest Manag Sci 69:478-482

Nunes A, Cosca KZ, Faggioni KM, Costa MLZ, Gonçalves RS, Walder JMM, Garcia MS, Nava DE (2013) Dietas artificiais para a criação de larvas e adultos da mosca-das-frutas sul-americana. Pesq Agropec Bras 48: 1309-1314

Paramasivam M, Selvi C (2017) Laboratory bioassay methods to assess the insecticide toxicity against insect pests-a review. J Entomol Zool Stud 5:1441-1445

Prokopy RJ, Cooley SS, Galarza L, Bergweiler C, Lauzon CR (1993) Bird droppings as natural food compete with bait sprays against Rhagoletis pomonella flies (Diptera: Tephritidae). Can Entomol 125: 413-422

Raga A, Galdino LT (2018) Mosca das frutas: Atração fatal. Cultivar 109: 20-23

Raga A, Sato ME (2005) Effect of spinosad bait against Ceratitis capitata (Wied.) and Anastrepha fraterculus (Wied.) (Diptera: Tephritidae) in laboratory. Neotrop Entomol 34:815-822

Raga A, Sato ME (2011) Toxicity of neonicotinoids to Ceratitis capitata and Anastrepha fraterculus (Diptera: Tephritidae). J Plant Prot Res 51: 413-419

Raga A, Galdino LT, Silva SB, Baldo FB, Sato ME (2018) Comparison of insecticide toxicity in adults of the fruit flies Anastrepha fraterculus (Wied.) and Anastrepha grandis (Macquart) (Tephritidae). J Exp Agric Int 25:1-8

Robertson JL, Russell RM, Preisler HK, Savin NE (2007) Bioassays with arthropods. CRC, Boca Raton

Rull J, Prokopy RJ (2000) Attraction of apple maggot flies, Rhagoletis pomonella (Diptera: Tephritidae) of different physiological states to odour-baited traps in the presence and absence of food. Bull Entomol Res 90:77-88

SAS Institute (2011) SAS System - SAS/STAT. computer program, version 9.2. By SAS Institute, Cary, NC. 84p.

Van Den Bosch TJM, Welte CU (2016) Detoxifying symbionts in agriculturally important pest insects. Microb Biotechnol 10:531-540

Yee LW, Alston DG (2016) Ovipostion of Rhagoletis indifferens (Diptera: Tephritidae) under low food availability. J Entomol Sci 51:101-112

Zart M, Fernandes OA, Botton M (2010) Biology and fertility life table of the South American fruit fly Anastrepha fraterculus on grape. Bull Insectol 63:237-242

Publisher's Note Springer Nature remains neutral with regard to jurisdictional claims in published maps and institutional affiliations. 